\title{
The Effect of Principal Leadership and Teacher Performance Toward Student Achievement
}

\author{
Intan Mayasari \\ Dinas Pendidikan OKU \\ e-mail: intanmutiara178@gmail.com \\ Yasir Arafat \\ Universitas PGRI Palembang \\ e-mail: yasirarafat@ univpgri-palembang.ac.id \\ Andi Arif Setiawan \\ Universitas PGRI Palembang \\ e-mail: andiarifsetiawan@univpgri-palembang.ac.id \\ Article History: Received on 10 November 2021, Revised on 10 December 2021 \\ Published on 14 December 2021
}

\begin{abstract}
This study determined the effect of principal leadership and teacher performance partially and simultaneously on student achievement. The research method is ex post facto with a total population of 53 teachers for the study sampling using total sampling so that the research sample is the same as the population, which is 53 respondents. Data collection techniques using documentation and questionnaires. The data analysis technique used the t-test and the f-test. The results of this study can be concluded that there is an influence of the principal's leadership and teacher performance partially and simultaneously on student achievement at Junior High School 02 Ogan Komering Ulu.
\end{abstract}

Keywords: Principal Leadership, Teacher Performance, Student Learning Achievement

\section{A. Introduction}

Education is the single most important element in defining the quality of human civilisation. According to RI Law No. 20 of 2003 governing the National Education System, education is a deliberate, organized endeavor to produce exceptional pupils. According to Nurlaeli and Saryono (2018), education is a component that cannot be isolated from other parts of human existence, both in a macro and micro sense, because every human being goes through an educational process. This phenomena indicates that education has a role in producing excellent human resources, and it even has a significant impact on the success or failure of development. More accurately, excellent education may create quality education. Personal abilities, thinking power, and better behavior can all be developed through education. Education is the primary indication of a nation's progress and improvement in the quality of its people resources. This is because the availability of sufficient quality human resources is critical to a country's development success. According to the mandate of the 1945 Constitution and its revisions (article 31 paragraph 2), the government continually tries to strengthen the human resources of the Indonesian population via education. 
Volume 2 (2) 2021

E-ISSN: 2723-6919 P-ISSN: 2746-0827

Education is one of the most important variables influencing societal quality (Mardalena et al, 2020). The expected level of education quality can be achieved by making systemic improvements to all aspects of education, such as principal leadership, improving the quality and equitable distribution of teachers, enhanced curriculum, learning resources, adequate facilities and infrastructure, a conducive learning climate, and government policies that support it. The teacher is the most important component of all since it is in the hands of the instructor that the curriculum, learning materials, facilities and infrastructure, and learning atmosphere become relevant for pupils (Mulyasa, 2004).

The standard of competence of educators and education professionals is one of the benchmarks that is directly connected to the quality of education. To accomplish high-quality education, instructors and education workers must be of high caliber. Education is the most important capital for developing superior human resources. The primary realm of education is school. The school has a vision, purpose, goals, and functions as an institution. The school's goal is to equip people to create changes and follow the global era. The school tries to increase students' self-ability so that they can progress, not just in the field of science. This skill might be physical, social, or emotional in nature.

Educational institutions are said to be of high quality if they have skilled instructors, a strong feeling of responsibility for their disciplines, and the lofty moral and character characteristics required to be acknowledged as educators. In this situation, educational institutions, such as schools, organize educational and learning activities based on innovative, creative, and efficient concepts in order to create excellent education (Sagala, 2017). Quality improvement in education is absolutely necessary, because it will have an impact on the quality of existing human resources. School organizations are made up of a variety of factors, including individuals and groups that collaborate to achieve educational goals. Without excluding other aspects of the school organization, the administrator and instructor are internal personnel who play a significant role in determining the effectiveness of a learning process.

The principle is one of the most important components of education in terms of boosting educational quality. In the context of regional autonomy and educational decentralization, the process of developing human resources must touch on numerous aspects of life that must be represented in the personalities of leaders, including educational leaders such as school principals. As a result, boosting the quality of human resources, particularly the principal as an education leader in schools, is a must for improving educational quality (Mulyasa, 2004).

As the school's highest leader, the principal wields considerable power and determines the school's progress; therefore, he must be capable of facilitating the smooth implementation of activities within the organization. Principals must be able to carry out their responsibilities for developing and maintaining a healthy and happy work environment, as well as carrying out their responsibilities for achieving organizational goals (Indrafachrudi, 2006).

As a leader, the principal must fulfill the duties and tasks of educators, managers, administrators, supervisors, leaders, innovators, and motivators (Permadi \& Arifin, 2010). This may be accomplished if a school principal can or can give strong example attitudes in conduct, attention to teacher replies, and chances for decision making in the organization in order to achieve the vision and purpose of the organization (Haryono and Arafat, 2017). If this is carefully considered, it will have a favorable effect on raising teacher morale. 
Volume 2 (2) 2021

E-ISSN: 2723-6919 P-ISSN: 2746-0827

Teachers range in their traits, demeanor, and work ethic; some are passionate and full of duty; others perform the task without a feeling of responsibility; and yet others frequently play truant, arrive late, and fail to comply. Teachers in such a state are an issue in every formal educational institution. Schools will struggle to attain the results that instructors anticipate when teachers perform poorly (Sardiman, 2005).

The instructor is one of the school's human resources. Teachers serve as role models and motivators for pupils as they chart their course for the future. If the instructor can be a source of inspiration and motivation for pupils, kids will be more likely to pursue their great ambitions in the future. This is where the significance of generating excellent instructors, ideal and inventive teachers capable of arousing enormous excitement in students to become players of changing world civilizations in this global era and capable of creating development in numerous disciplines comes into play. This transformation is also dependent on how the principal implements the best method for maximizing teachers' roles in achieving school goals and enhancing learning quality (Suliah et al, 2019).

The presence of competent professors is undoubtedly expected to bring Indonesian education quality closer to the targeted level. Quality problems relate to graduate competencies, including outputs and results, and encompass educational processes and outcomes. The primary focus of educators in the twenty-first century is to prepare students for life and work in a society where quality learning and education must be continually enhanced (Tilaar, 1999).

Teachers play an important role in education; even adequate other educational resources are often rendered ineffective if they are not accompanied by adequate teacher quality; in other words, teachers are the driving force behind efforts to improve the quality of services and educational outcomes (Murwati, 2013). Teacher performance is one of the indicators of educational achievement. Teacher performance is essentially a teacher's activity in carrying out his responsibilities and obligations as a teacher and educator in schools, which might characterize his work performance in carrying out everything (Suharsaputra, 2010). Furthermore, teacher performance may be viewed as a condition that demonstrates a teacher's capacity to carry out his tasks and characterizes the behaviors performed by the instructor during the learning process (Supardi 2013).

According to the Regulation of the Minister of National Education of the Republic of Indonesia No. 16 of 2007 concerning Academic Qualification Standards and Teacher Competencies, teacher competency standards are fully developed into four main competencies, namely (a) pedagogic competence, (b) personality competence, (c) professional competence, (d) and social competence. Of course, the four skills that constitute the norms of academic credentials and teacher competences must be properly grasped by the instructor. These skills can be used as a reference in measuring teacher performance; if the instructor meets or exceeds the competency requirements established, the teacher's performance can be considered good.

Competence is defined as knowledge, skills, attitudes, and values expressed in a way of thinking and behaving. A person can become competent by developing the habit of regularly thinking and doing. This suggests that a person's competence might take the shape of knowledge, skills, and fundamental beliefs. Competence may be defined by a variety of learning outcomes, and its indicators can be assessed and monitored (Trianto and Tutik, 2007). Ideally, the expected teacher is one who has the authority to assess teachers' effectiveness in carrying out their responsibilities and roles professionally. This embodiment is mirrored in his 
Volume 2 (2) 2021

E-ISSN: 2723-6919 P-ISSN: 2746-0827

instructional quality. Interactions with students, relationships with colleagues, relationships with other parties, attitudes, and professional abilities are all important. Because the teacher is at the core of teaching and learning activities, the teacher is a decisive factor in the effectiveness of education in schools. A teacher's aptitude or competency has a significant impact on teacher performance (Aqib, 2009).

Teacher performance is a procedure that is carried out by all components of the school, including instructors, principals, and students, in order to enhance the learning quality of pupils. According to Kompri (2014), performance or job performance is an English translation of the term performance. Performance is directly tied to the accomplishments that a person or institution must achieve in carrying out their tasks. As a result, teacher performance is inextricably linked to the process of organizing and administering education through the distribution of duties and functions within the school. If the process of organizing and executing education management goes smoothly, achieving the goals will be simple.

Teacher performance is still an issue that requires addressed. One of the symptoms is a lack of discipline and instructor understanding of subject matter, as well as ineffective teaching techniques. As a result, the quality of the profession, as well as the quality and competency of instructors, is still judged inadequate. Teacher performance that is centered toward theory mastery and memory leads students' capacities to grow in an inefficient and unbalanced manner (Pudjiastuti, et al, 2011). Low teacher performance is expected as a result of several factors both inside and outside of individual instructors. Furthermore, low teacher performance is determined by factors such as competency, work discipline, job happiness in the organization where the teacher teaches, principal leadership, and the availability of government education programs (Astuti et. al, 2020; Maryati et. al, 2020; Ibrahim et. al, 2020). According to Siagian (2010), performance is impacted by a variety of elements such as work environment, organizational culture, leadership and work motivation, work discipline, compensation, job satisfaction, and others.

Teachers play a critical role in enhancing the quality of their performance. Almost all educational reform attempts, such as curriculum implementation and the use of novel teaching methods, are ultimately dependent on the teacher. Without them, attempts to encourage pupils to reach high levels of accomplishment would not provide the best benefits. Students should strive for success because high performance will serve as a barometer for all aspects of education, particularly the performance of great teachers. This is due to the necessity of understanding students' learning performance, both individually and in groups, because learning achievement serves not only as an indicator of success in a certain field of study, but also as an indicator of the quality of educational institutions. Furthermore, learning accomplishment serves as feedback for teachers while they carry out the learning process, allowing them to assess whether it is required to diagnose, place, or coach children (Arifin, 2009).

Individuals make a conscious effort to satisfy their needs through learning. Learning is the process through which a person obtains a new behavior modification as a result of his own experience in connection with his environment (Slameto, 2010). Learning is a critical process for modifying everyone's behavior, and it encompasses everything a person thinks and does (Rifa'i and Chaterina, 2009). Student learning accomplishment may be used to evaluate the effectiveness of the learning process in schools. Learning accomplishment is the mastery of 
information or skills developed by subjects, as measured by test scores or instructor ratings (Tulus, 2004).

Every learning activity that students engage in will result in changes in themselves. Bloom and his colleagues categorize them as cognitive, emotional, and psychomotor. Learning accomplishment is the outcome obtained by pupils following a period of study. The term "learning outcomes" refers to students' total learning accomplishment, which is a measure of competency and the degree of behavior change (Mulyasa, 2004).

According to Listyasari (2013) and Lestari (2016) research, principals' leadership and teacher effectiveness have a favorable influence on student accomplishment. Hendrawati and Prasojo (2015) conducted research with the following findings: (1) there is a direct influence of the principal's transformational leadership on student achievement, (2) there is an indirect influence of the principal's transformational leadership on student learning achievement through teacher work motivation, (3) there is a direct influence of school culture on student achievement, and (4) there is an indirect influence of school culture on student chievement through teacher work motivation, (5) there is a link between teacher work motivation and student accomplishment. According to Supriadi (2016), there is a positive and significant contribution to the leadership of the madrasa principal on student achievement, (2) there is a positive and significant contribution to the work ability of teachers on student achievement, an increase in the work ability of teachers is followed by an increase in student achievement, (3) the leadership of the madrasa principal, teacher work ability, and organizational climate have a positive and significant contribution to student achievement.

State Junior High School 02 OKU is a well-liked institution in Baturaja. The school's results are not less competitive with the subsequent appearance of newly founded institutions. This accomplishment is unquestionably endorsed by all parties in SMP Negeri 02 OKU. However, based on observations, there are still issues affecting the quality of learning at SMP Negeri 02 OKU, such as (1) around 35 percent of students still have scores below the KKM, and Improved Student Achievement at SMP Negeri 02 Ogan Komering Ulu has not seen a significant change, (2) teacher performance is still less than optimal, and nearly 40 percent of teachers are less active in designing and implementing learning evaluation. The principal has not been overbearing and is concerned with the advancement of student accomplishment in school. Based on some of these findings, it has been determined that further study is required in order to improve student accomplishment.

The preceding background demonstrates that more study is required to overcome challenges that develop in the subject. As a result, the researchers performed a study titled "Analysis of Principal Leadership and Teacher Performance on Student Achievement at SMP Negeri 02 Ogan Komering Ulu."

\section{B. Methods}

The study was carried out in State Junior High School 02 Ogan Komering Ulu Regency. Jln. Bll Kulon No. 0808 Kel. Kemalaraja district, East Baturaja, Kab. Ogan Komering Ulu, South Sumatra With the kind of correlational research, this study employs a quantitative descriptive approach, in which the data acquired is realized in the form of numbers and evaluated using statistics (Sugiyono, 2019). The purpose of this research is to determine the link between one variable and another. Correlation study is an example of ex-postfacto research since researchers 
Volume 2 (2) 2021

E-ISSN: 2723-6919 P-ISSN: 2746-0827

often do not modify the existing variable conditions and instead look for the existence and amount of variable association, as represented in Sukardi's (2008) correlation coefficient. Expost atory research design is study that tries to analyze events that have occurred and then trace back to determine the variables that caused these events to occur. The research sample in this study consisted of 53 instructors from SMPN 2 Ogan Komering Ulu. In this study, questionnaires and documentation were used to collect data. SPSS was used to do the data analysis.

\section{Results and Discussion}

\section{The Influence of Principal's Leadership on Student Achievement}

One of the principal's responsibilities is to lead the staff (teachers and employees), fostering harmonious cooperation among staff members so that they can raise morale, teacher performance for the staff they lead, and create a conducive environment. Good leadership, healthy teamwork, and a conducive environment guarantee that employees are delighted to do their jobs to the best of their abilities. Furthermore, the principal's leadership is critical to the process of empowering instructional activities in schools.

The principal's influence, capacity to apply that influence, and the implications of that influence for those who desire to be influenced, notably teachers, students, staff, and other school members, are all elements of his leadership. The principal's leadership role, comprising charisma, idealized influence, inspiring motivation, intellectual stimulation, and individual consideration, is used to achieve this impact. The management of the principal's leadership function can have an impact on student accomplishment, making it easier to attain educational goals.

As a result, principle leadership is required to improve student accomplishment. The results showed that the principal's leadership had a positive and significant influence on student learning achievement, as evidenced by the value of the hypothesis testing results, where the probability value (0.000) is less than the value of (0.05), and the tcount value (5.257) is greater than the ttable value (1.686), implying that $\mathrm{Ha}$ is accepted. That is, the principal's leadership has an impact on student achievement. The principal's leadership has a 33.9 percent effect on student learning attainment; the remaining 66.1 percent is influenced by non-variable factors.

Based on the above description, it is possible to deduce that the better the principal's leadership, the higher the student's learning accomplishment, and the poorer the principal's leadership, the lower the student's learning achievement.

\section{The Effect of Teacher Quality on Student Achievement}

A teacher, in addition to the administrator, plays a significant function in educational institutions. If the principal's position is more functional in terms of management, the teacher's role dominates the learning component, beginning with planning, executing, assessing learning outcomes, and implementing follow-up on assessment findings. A teacher's performance may be measured using the four phases of learning.

The hypothesis testing findings show that the probability value $(0.000)$ is less than the value (0.05), and the value of tcount (5.387) is more than the value of ttable (1.686), implying that 
Volume 2 (2) 2021

E-ISSN: 2723-6919 P-ISSN: 2746-0827

$\mathrm{Ha}$ is accepted. That is, teacher performance has a considerable influence on student accomplishment in SMP Negeri 02 OKU. The effect of teacher performance on student learning attainment is 36.3 percent, with the remaining 63.7 percent influenced by other factors not studied in this study.

Based on the preceding description, it is possible to deduce that the better the teacher's performance, the better the student's learning accomplishment, and vice versa, the poorer the teacher's performance, the lower the student's learning achievement.

\section{Principal Leadership and Teacher Performance's Impact on Student Achievement}

The study's findings indicate that there is a positive and significant relationship between the principal's leadership and teacher performance and student achievement, as evidenced by the value of the hypothesis testing results, where the probability value $(0.000)$ is less than the value of (0.05), and Fcount value of 22.441 is greater than $\mathrm{F}(0.05)$ (1:53) of 4.02, indicating that $\mathrm{Ha}$ is accepted. That is, the principal's leadership and teacher effectiveness have a major impact on student accomplishment.

The combined effect of principal leadership and teacher performance on student success is 47.3 percent; the remaining 52.7 percent is influenced by other factors not included in this study's variables. Many factors that affect student learning achievement, including principals' leadership and teacher performance, are essentially the result of interactions between these various factors, where the results of this study also show that principals' leadership and teacher performance make an effective contribution of $47.3 \%$ on student achievement.

As a result, the principal's leadership and teacher effectiveness influence student accomplishment. The higher the level of student learning accomplishment, the better the principal's leadership and teacher effectiveness.

\section{Conclusion}

The leadership of the principle has a substantial impact on student success. The performance of teachers has a substantial impact on student learning achievement. At SMP Negeri 02 Ogan Komering Ulu, principal leadership and teacher effectiveness have a substantial impact on student accomplishment.

\section{E. Acknowledgement}

We thank to Rector Universitas PGRI Palembang, Dinas Pendidikan Propinsi OKU and friends who have supported us to do this project.

\section{References}

Arifin, Z. (2009). Evaluasi Pembelajaran [Learning Evaluation]. Bandung: Rosdakarya.

Astuti, R. W., Fitria, H., \& Rohana, R. (2020). The Influence of Leadership Styles and Work Motivation on Teacher's Performance. Journal of Social Work and Science Education, 1(2), 105-114. https://doi.org/10.52690/jswse.v1i2.33 
Aqib, Z. (2009). Penelitian Tindakan Kelas Untuk Guru [Classroom Action Research For Teachers]. Bandung: YramaWidya.

Haryono, S., \& Arafat, Y. (2017). Effects of Organizational Culture and Work Motivation on Job Performance Among the Private Universities' Full-time Faculties in South Sumatera Province. Information, 20(8).

Hendrawati, A., \& Prasojo, L. D. (2015). Pengaruh Kepemimpinan Transformasional Kepala Sekolah, Motivasi Kerja Guru, Dan Budaya Sekolah Terhadap Prestasi Belajar [The Influence of Principal Transformational Leadership, Teacher Work Motivation, and School Culture on Learning Achievement]. Jurnal Akuntabilitas Manajemen Pendidikan, 3(2).

Ibrahim, I., Fitria, H., \& Puspita, Y. (2020). The Effect of Work Discipline and Teacher's Motivation on Teacher's Performance. Journal of Social Work and Science Education, 1(2), 140-145. https://doi.org/10.52690/jswse.v1i2.41

Indrafachrudi, S. (2006). Bagaimana Memimpin Sekolah Yang Efektif [How to Lead an Effective School]. Bogor: Ghalia Indonesia

Kompri. (2014). Manajemen Sekolah Teori dan Praktek [School Management Theory and Practice]. Bandung: Alfabeta.

Lestari, S. (2016). Pengaruh Kepemimpinan Kepala Sekolah Dan Kinerja Guru Terhadap Prestasi Siswa [The Influence of Principal Leadership and Teacher Performance on Student Achievement]. Jurnal Satya Widya, 32(2).

Listyasari, E. (2013). Pengaruh kepemimpinan kepala sekolah dan kinerja guru terhadap prestasi belajar siswa di SMA Negeri se-kota Tasikmalaya [The influence of principals' leadership and teacher performance on student achievement in state high schools throughout the city of Tasikmalaya]. Jurnal Ilmiah Mahasiswa Pascasarjana Administrasi Pendidikan, 1(1).

Mardalena., Arafat, Y. \& Fitria, H. (2020). Pengaruh Supervisi Akademik dan Kompetensi Profesional Guru terhadap Kinerja Guru di Sekolah Menengah Atas Negeri di Kecamatan Tanjung Raja [The Effect of Academic Supervision and Teacher Professional Competence on Teacher Performance in Public High Schools in Tanjung Raja District]. Jurnal Intelektualita: Keislaman, Sosial, dan Sains, 9(1).

Maryati, E., Fitria, H., \& Rohana, R. (2020). The Influence of Principal's Leadership Style and Organizational Culture on Teacher's Performance. Journal of Social Work and Science Education, 1(2), 127-139. https://doi.org/10.52690/jswse.v1i2.38

Mulyasa, E. (2004). Menjadi Kepala Sekolah Profesional Dalam Konteks Menyukseskan MBS dan KBK [Becoming a Professional School Principal in the Context of Succeeding SBM and $K B K]$. Bandung: Remaja Rosda Karya.

Murwati, H. (2013). Pengaruh Sertifikasi Profesi Guru terhadap Motivasi Kerja dan Kinerja Guru di SMK Negeri Se- Surakarta [The Effect of Teacher Professional Certification 
on Work Motivation and Teacher Performance in State Vocational Schools in Surakarta]. Jurnal Pendidikan Bisnis dan Ekonomi (BISE), 1(1).

Nurlaeli, Y., \& Saryono, O. (2018). Efektivitas Musyawarah Guru Mata Pelajaran (MGMP) Dalam Meningkatkan Kinerja Mengajar Guru Bahasa Inggris [The Effectiveness of Subject Teacher Deliberations (MGMP) in Improving Teaching Performance of English Teachers]. Indonesian Journal of Education Management and Administration Review, 2(2).

Peraturan Menteri Pendidikan Nasional Republik Indonesia Nomor 16 Tahun 2007 [Regulation of the Minister of National Education of the Republic of Indonesia Number 16 of 2007]

Permadi, D. P., \& Arifin, D. (2010). Kepemimpinan Trasformasional Kepala Sekolah dan Komite Sekolah [Transformational Leadership of Principals and School Committees]. Bandung: Sarana Panca Karya Nusa.

Pudjiastuti, E., \& Sriwidodo, U. (2011). Pengaruh Kompetensi, Disiplin Kerja, dan Kepuasan Kerja terhadap Kinerja Guru SMP Negeri 1 Purwodadi Grobogan [The Influence of Competence, Work Discipline, and Job Satisfaction on Teacher Performance at SMP Negeri 1 Purwodadi Grobogan]. Jurnal Manajemen Sumberdaya Manusia, 5(2).

Rifa'i, A., \& Catharina, T. A. (2009). Psikologi Pendidikan [Educational Psychology]. Semarang: Universitas Negeri Semarang Press.

Sagala, S. (2017). Manajemen Strategik Dalam Peningkatan Mutu Pendidikan [Strategic Management in Improving the Quality of Education]. Bandung: Alfabeta

Sardiman. (2005). Interaksi dan Motivasi Belajar Mengajar [Teaching and Learning Interaction and Motivation]. Jakarta: Raja Grafindo Persada

Siagian, S. P. (2010). Manajemen Sumber Daya Manusia [Human Resource Management]. Jakarta: Bumi Aksara

Slameto. (2010). Belajar dan Faktor-Faktor yang Mempengaruhinya [Learning and the Factors That Affect It]. Jakarta: Rineka Cipta

Sugiyono. (2019). Metode Penelitian Kuantitatif, Kualitatif dan $R \& D$ [Quantitative, Qualitative and R\&D Research Methods]. Bandung: Alfabeta

Suharsaputra, U. (2010). Administrasi Pendidikan [Education administration]. Bandung: Refika Aditama

Sukardi. (2008). Metodologi Penelitian Pendidikan, Kompetensi dan Praktiknya [Educational Research Methodology, Competence and Practice]. Jakarta: Bumi Aksara.

Suliah., Harapan, E., \& Arafat, Y. (2019). Headmaster's Strategy To Maximizes Using Infrastructure And Teachers' Role To Improve Learning Quality In Elementary School. International Journal Of Scientific \& Technology Research, Vol 8. 
Supardi. (2013). Kinerja Guru [Teacher Performance]. Jakarta: Raja Grafindo Persada.

Supriadi, E. (2016). Kontribusi Kepemimpinan Kepala Madrasah, Kemampuan Kerja Guru Dan Iklim Organisasi Terhadap Prestasi Belajar Siswa MTs Negeri Jakarta Selatan [The Contribution of Madrasah Principal Leadership, Teacher Work Ability and Organizational Climate to Student Achievement at MTs Negeri Jakarta Selatan]. TANZIM Jurnal Penelitian Manajemen Pendidikan, 1(2).

Tilaar. (1999). Beberapa Agenda Reformasi Pendidikan dalam Perspektif Abad 21 [Several Agendas for Educational Reform in the Perspective of the 21st Century]. Magelang: Indonesia Tera

Tulus, T. (2004). Peran Disiplin pada Perilakudan Prestasi Belajar [The Role of Discipline on Behavior and Learning Achievement]. Jakarta: Grasindo

Trianto dan Tutik, T. (2007). Sertifikasi Guru Dan Upaya Peningkatan Kualifikasi, Kompetensi \& Kesejahteraan [Teacher Certification and Efforts to Improve Qualifications, Competence \& Welfare]. Jakarta: Prestasi Pustaka Publisher.

Undang-Undang Dasar 1945 [1945 Constitution]

Undang-Undang RI No 20 Tahun 2003 [Undang-Undang RI No 20 Tahun 2003] 